\title{
CREATIVE DESIGN OF BUILDINGS AND STRUCTURES
}

\author{
Haqberdiyev B.R.
}

The Head of The Department, Fine Arts And Engineering Graphics, Andijan State University, Uzbekistan

\author{
Rustamov U.
}

Teacher Of Fine Arts And Engineering Graphics, Andijan State University, Uzbekistan

\section{ABSTRACT}

This article provides information on the design and efficient use of buildings and structures to improve the integration of engineering graphics and design sciences, the construction of quality housing. The article in your hand is drawing and design in a cycle of engineering graphics and design sciences on improving the integration of themes, in which architectural approaches are described by nature in relation to the set of colors used by artists as well as modest decorators, architects and designers. buildings are also covered.

KEYWORDS:- Integration, engineering graphics, design, development, cultural, architecture, nature, designing architectural elements, patterns, drawing, knowledge and skills, the art of architecture, the art of carving, general plan, architectural drawings, interior, reinforced concrete structures, residential, school, business, hospital, gravel, sand.

\section{INTRODUCTION}

Indeed, architecture and design are truly a work of fine art, a technique that inspires and excites the human spirit. First of all, a talent given by God is needed to create such an inanimate but uplifting spiritual joy, a 'work' that gives pleasure secondly, needed various construction materials for a composition created from a collection of charms, decorative fine lines. The book in your hand is the first textbook in which architectural approaches are described in respect of the collection of colors gifted by nature used by artists, as well as humble decorators, architects, and designers, as building materials used in the construction of practically unique buildings.
Suppose, underground resources, natural stones - they all have special color. For example, there are dozens of colors of sand or gravel used in concrete. For instance, when you cut wood you will see everywhere different color directions. These are all of certainly natural colors. Construction materials extracted from such raw materials are resistant to discoloration even in the light of harsh weather and climatic conditions. That is, the surface remains shiny even when they are exposed to the high temperatures of the sun, the fresh water of the rain, and even when they are frozen. When building a large structure (or any building), the reader needs to know about the architectural items, in particular, taking into account in which part of the building they are used, all physical 
CURRENT RESEARCH JOURNAL OF PEDAGOGICS 2(9): 76-78, September

2021 DOI: https://doi.org/10.37547/pedagogics-crjp-02-09-16

ISSN 2767-3278

(C)2021 Master Journals

\section{Crossref dof 81 Google}

Accepted 25th September, 2021 \& Published 30 ${ }^{\text {th }}$ September, 2021

and mechanical properties - durability of the item, that it does not change color, and resistance to water and cold. This textbook provides a brief overview of the types of building materials needed to repair and decorate buildings and structures, their properties, the technology of processing raw materials, and the use of the materials obtained. With regard to designing, the volume of research work is constantly growing, as well year by year additional engineering and economic requirements are placed on projects that are being developed to accommodate enterprises in a variety of complex environments.

It is impractical to build structures without a preliminary design and estimate, because we need to know before and after the start of construction work, where and how construction will take place, how much it will cost, how much and what building materials, labor resources, equipment will be needed, how long construction will take, whether the construction and operation of the intended object will be economical. The design and estimate includes the answers to these questions. It is critical to address the important matters and engineering issues in the design. It is important to determine and select the most efficient method of production for a particular situation, the size and quantity of equipment and machinery, as well as the optimal operation of the equipment. The

subtlety of the design is that many engineering problems are closely connected and their solution depends on geographical (construction site, distance of transportation of raw materials and products, climate), social (labor protection and environment, housing, living conditions of workers). ) and economic (capital expenditures, product cost, potential to cover the costs etc.) factors. The most important economic issues of design include: 1) finding the optimal relationship between people, industry and nature; 2) taking into account the factors of the internal enterprise that provide the most optimal design of production; 3) selection of optimal volume planned and effective construction materials; 4) taking into account the sanitary conditions in increasing labor productivity.

Some small businesses, their components, and entire businesses are made up of a variety of distinct products, or the proposed business's surroundings is the subject of design. This construction's design phase is the first step in the process. The feasibility study's quality and high degree of design will be determined by the predicted construction cost, construction length, and capital expenditure efficiency.

\section{REFERENCES}

1 Valiyev A.N.,, Haqberdiyev B.R., Gulomova N.X., Boboyeva Z.A "Drawing” (mechanical drawing) Tashkent 2020

2 Haqberdiev Bakhtiyor Rustamovich Designing of architectural elements DOI: http://doi.org/10.5281/zenodo.4716849 Primedia E-launch LLC, 5518 Flint St, Shawnee, 66203, USA

3 Haqberdiyev, B.R. (2021). Goals and objectives of pedagogical experimental work. International Engineering Journal For Research \& Development, 6(3), 2-2. 2021

4 Haqberdiyev. B.R. "Design of architectural elements" - Tashkent ;; Fan Ziyosi Publishing House 2021

5 Haqberdiyev, B. R., Kochkarov, B., \& Mamitaliyev, A. (2020). Contents, value of interdisciplinary relations. European Journal of Molecular \& Clinical Medicine, 7(2), 476-479.

6 Nasritdinova, U., \& Khahkberdiyev, B. 
CURRENT RESEARCH JOURNAL OF PEDAGOGICS 2(9): 76-78, September

2021 DOI: https://doi.org/10.37547/pedagogics-crjp-02-09-16

ISSN 2767-3278

(C)2021 Master Journals

Crossref doi Google

Accepted 25 $5^{\text {th }}$ September, $2021 \&$ Published 30 $0^{\text {th }}$ September, 2021

(2020, July). Results theoretical study of the form of a front surface of a chiselcultivator stand. In IOP Conference Series: Materials Science and Engineering (Vol. 883, No. 1, p. 012108). IOP Publishing 